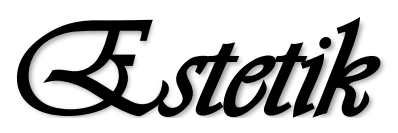

Jurnal Bahasa Indonesia
Institut Agama Islam Negeri (IAIN) Curup, Indonesia

ISSN 2622-1810 (p); 2622-1829 (e)

volume 4, number 1, 2021 | page: 37-54

DOI: http://doi.org/10.29240/estetik.v4i1.2209

\title{
Fungsi, Peran, dan Kategori Sintaksis Bahasa Indonesia dalam kalimat Berita dan Kalimat Seruan pada Naskah Pidato Bung Karno 17 Agustus 1945
}

\author{
Armita Enggarwati, Asep Purwo Yudi Utomo \\ Universitas Negeri Semarang, Indonesia \\ armitasaja16@students.unnes.ac.id, aseppyu@mail.unnes.ac.id
}

\begin{abstract}
The manuscript of Bung Karno's speech on August 17, 1945 is an example of the use of Indonesian in official documents and state speeches so that the sentences in them are good to analyze. There are many syntactic symptoms found in it that are interesting to study, including the structure of descriptive sentences and imperative sentences which can be analyzed based on the functions, roles, and syntactic categories of Indonesian. This research consists of two problems, namely (1) regarding the functions, roles, and syntactic categories of news sentences in Bung Karno's speech on August 17, 1945, (2) regarding the functions, roles, and syntactic categories of exclamatory sentences in Bung Karno's speeches on August 17, 1945. This study aims to describe the types of functions, roles, and syntactic categories of news sentences and exclamations of Bung Karno's speech on August 17, 1945. The research method used is descriptive qualitative research method. Data collection was carried out using the note-taking technique and data analysis using content analysis techniques. The results of this study found that syntactic functions include subject, predicate, object, description, and complement; the roles that are found are as actors, tools, and experiences occupying the function of the subject; and categories include pronouns, nouns, transitive verbs, intransitive verbs, adverbial phrases, verbal phrases, nominal phrases, prepositional phrases, adjective phrases, and numeral phrases. From this research, it can be seen that one sentence can contain more than one type of function, role, and syntactic category. This research is expected to show the functions, roles, and syntactic categories in declarative and imperative sentences in Bung Karno's speech on August 17, 1945, which is the speech of the proclamation of Indonesian independence.
\end{abstract}

Keywords: Function, Role, Category, Syntax, News Sentence, Exclamation Sentence

Abstrak. Naskah pidato Bung Karno 17 Agustus 1945 merupakan contoh penggunaan bahasa Indonesia dalam dokumen resmi dan pidato kenegaraan sehingga kalimat di dalamnya merupakan kalimat yang bagus untuk dianalisis. Banyak ditemukan gejala sintaksis di dalamnya yang menarik untuk diteliti, di antaranya adalah struktur kalimat berita dan kalimat seruan yang dapat 
dianalisis berdasarkan fungsi, peran, dan kategori sintaksis bahasa Indonesia. Penelitian ini terdiri atas dua permasalahan, yaitu (1) mengenai fungsi, peran, dan kategori sintaksis pada kalimat berita dalam naskah pidato Bung Karno 17 Agustus 1945, (2) mengenai fungsi, peran, dan kategori sintaksis pada kalimat seruan dalam naskah pidato Bung Karno 17 Agustus 1945. Penelitian ini bertujuan untuk mendeskripsikan jenis fungsi, peran, dan kategori sintaksis kalimat berita dan kalimat seruan naskah pidato Bung Karno 17 Agustus 1945. Metode penelitian yang digunakan adalah metode penelitian deskripstif kualitatif. Pengumpulan data dilakukan dengan mengunakan teknik simak catat dan analisis data menggunakan teknik analisis isi. Hasil penelitian ini ditemukan fungsi sintaksis meliputi subjek, predikat, objek, keterangan, dan pelengkap; peran yang ditemukan adalah sebagai pelaku, alat, dan pengalam menduduki fungsi subjek; dan kategori meliputi pronomina, nomina, verba transitif, verba intransitif, frasa adverbial, frasa verbal, frasa nominal, frasa preposisional, frasa adjektival, dan frasa numeralia. Dari penelitian ini dapat diketahui bahwasanya dalam satu kalimat dapat mengandung lebih dari satu jenis fungsi, peran, dan kategori sintaksis. Penelitin ini diharapkan dapat menunjukkan fungsi, peran, dan kategori sintaksis dalam kalimat deklaratif dan imperatif pada naskah pidato Bung Karno 17 Agustus 1945 yang merupakan pidato proklamasi kemerdekaan Indonesia.

Kata Kunci: Fungsi, Peran, Kategori, Sintaksis, Kalimat Berita, Kalimat Seruan

\section{Pendahuluan}

Bahasa adalah fenomena yang menghubungkan dunia makna dengan dunia bunyi. Lalu, sebagai penghubung di antara kedua dunia itu, bahasa dibangun oleh tiga buah komponen, yaitu komponen leksikon, komponen gramatika, dan komponen fonologi (Chaer, 2015). Bahasa memiliki peranan yang sangat penting dalam kehidupan manusia yakni sebagai sarana komunikasi. Bahasa dibagi menjadi dua bagian, yakni bahasa verbal atau lisan dan bahasa nonverbal atau bahasa tulisan. Dalam bahasa tulisan terdapat komponen gramatika yang dikenal adanya kata, frasa, klausa, kalimat yang dapat menjadi wacana dibahas dalam sintaksis.

Sukini menjelaskan bahwa sintaksis adalah cabang ilmu bahasa yang membicarakan seluk-beluk frasa, klausa, kalimat, dengan satuan terkecilnya berupa bentuk bebas, yaitu kata (Wahyuni R. T., 2019). Ramlan (1987:151) dalam (Nisrina, 2011) mendefinisikan frasa sebagai satuan gramatikal yang terdiri dari dua kata atau lebih yang tidak melampaui batas fungsi unsur klausa. Sasangka (2008:162) dalam 
(Nisrina, 2011) menyatakan klausa adalah untaian kata yang sudah berarti. Alwi (2003:311) dalam (Nisrina, 2011) menyatakan bahwa kalimat adalah satuan bahasa terkecil dalam wujud lisan atau tulisan, yang mengungkapkan pikiran yang utuh.

Chaer menyatakan bahwa kajian sintaksis membedah beberapa unsur penting, misalnya, fungsi, kategori, dan peran sintaksis (Samu A. Y., 2018). Sintaksis memiliki fungsi, peran, dan kategori dalam setiap kalimat. Analisis fungsi, kategori, dan peran merupakan kajian sintaksis yang menelaah unsur-unsur yang terdapat dalam sebuah kalimat, kategori kata yang menduduki setiap fungsi kalimat, dan peran semantisnya (Taib, 2014). Fungsi sintaksis disebut juga fungsi gramatikal. Fungsi sintaksis mencakup mencakup subjek, predikat, objek, pelengkap, dan keterangan yang harus diisi kategori tertentu. Fungsi sintaksis merupakan tempat kosong yang berisikan sesuatu yang berupa kategori dan memiliki peran tertentu. Fungsi sintaksis meliputi subjek, predikat, objek, pelengkap, dan keterangan. Kategori sintaksis adalah bentuk-bentuk tertentu yang mengisi fungsi sintaksis. Kategori tersebut berupa kelas kata, yaitu nomina, pronomina, verba, adjektiva, adverbia, preposisi, dan lain-lain. Peran sintaksis adalah makna semantis tertentu yang mengisi fungsi sintaksis. Peran tersebut mencakup makna semantis, yaitu aktif, pasif, statif, posesif, pelaku, penerima, dan lain-lain (Wahyuni R. T., 2019)

Fungsi, peran, dan kategori sintaksis tersebut dapat ditemui dalam sebuah kalimat. Kalimat adalah susunan kata-kata yang teratur yang berisi pikiran yang lengkap (Chaer, 2012). Kalimat menjadi bagian penting dalam pidato apalagi pidato resmi kenegaraan. Seperti pada pidato Bung Karno 17 Agustus 1945, peristiwa bersejarah yang harus selalu diingat oleh seluruh bangsa Indonesia yaitu peristiwa proklamasi kemerdekaan Indonesia. Dalam naskah pidato Bung Karno 17 Agustus 1945 tersebut, banyak terdapat kalimat berita dan kalimat seruan. Kalimat berita atau kalimat deklaratif merupakan kalimat yang mengandung intonasi deklaratif dan pada umumnya mengandung makna menyatakan atau memberitahukan sesuatu. Sedangkan kalimat seruan atau kalimat imperatif merupakan kalimat yang mengandung intonasi imperatif pada umumnya mengandung makna perintah atau larangan 
(Kridalaksana, 2008). Kalimat-kalimat yang digunakan dalam naskah pidato Bung Karno 17 Agustus 1945 tersebut perlu dianalisis fungsi, peran, dan kategori sintaksisnya untuk mengetahui bagaimana gramatika yang digunakan pada naskah pidato untuk menyampaikan Bung Karno 17 Agustus 1945.

Terdapat penelitian yang relevan dari beberapa peneliti bahasa, diantaranya adalah yang (Mayasari, 2017). mengkaji mengenai peran dan fungsi sintaksis bahasa Indonesia pada kalimat deklaratif dan kalimat interogatif dalam rubrik harian Jawa Pos, (Taib, 2014) mengkaji tentang kategori, fungsi, dan peran sintaksis dalam kalimat bahasa Aceh, (Irmansyah, 2015) mengkaji tentang struktur kalimat bahasa Muna yang di dalamnya termasuk peran dan kategori sintaksis, (Wahyuni R. T., 2019) mengkaji tentang pola, fungsi, kategori, dan peran sintaksis pada kalimat tunggal dalam surat kabar harian Kompas, (Trisnawati A. , 2015) mengkaji tentang fungsi, kategori, dan peran sintaksis dalam kalimat pupuh Durma dalam geguritan Tirta Amerta, (Susandhika, Laksana, \& Suparwa, 2016) mengkaji tentang fungsi, kategori, dan peran sintaksis dalam Talk Show One Lawyers Club TV One, (Mayasari \& Ardhana, 2018) mengkaji tentang publikasi bentuk fungsi dan kategori sintaksis tuturan masyarakat Manduro sebagai pendukung perkembangan bahasa anak usia dini, (Mardhatillah, 2016) mengkaji suatu analisis sintaksis mengenai fungsi dan kategori kalimat sederhana dalam jurnal English Teaching Forum, (Sako, Roekhan, \& Sunoto, 2017) mengkaji tentang kesalahan berbahasa tataran sintaksis pada penulisan pengalaman pribadi siswa kelas X SMA, (Syahroni \& Harsono, 2019) mengkaji tentang aplikasi penentuan kategori dan fungsi sintaksis kalimat bahasa Indonesia, (Astuti, 2017) mengkaji tentang fungsi sintaksis kata apa dan mana dalam bahasa Indonesia, (Lestari, 2018) mengkaji tentang struktur kalimat biografi Cut Nyak Dien dan implikasinya di SMA yang di dalamnya terdapat pembahasan fungsi sintaksis, (Wahyuni R. T., 2019) membahas tentang pola, fungsi, kategori, dan peran sintaksis pada kalimat tunggal dalam surat kabar harian Kompas serta relevansinya dengan pembelajaran bahasa Indonesia di SMP, (Erni, 2016) mengkaji tentang fungsi, kategori, dan peran pronominal persona bahasa Muna dialek Kambowa, (Samu A. Y., 2018) mengkaji tentang fungsi sintaksis dan peran 
semantis argumen inti bahasa Manggarai dialek Manggarai Tengah, (Iswara A. A., 2015) mengkaji tentang fungsi sintaksis dan peran semantik argumen frasa verba bahasa Bali, (Usman \& Amir, 2019) mengkaji tentang pengaruh kompetensi sintaksis terhadap keterampilan menulis eksposisi mahasiswa prodi pendidikan bahasa Indonesia UNM yang di dalamnya juga terdapat pembahasan mengenai struktur sintaksis meliputi fungsi, peran, dan kategori sintaksis.

Dari beberapa penelitian di atas, terdapat persamaan dan perbedaan terhadap penelitian yang dilakukan. Semua penelitian tersebut mengkaji tentang peran, fungsi, pola, dan kategori sintaksis. Peneliti di sini mengkaji tentang fungsi, peran, dan kategori sintaksis bahasa Indonesia pada salah satu kalimat berdasarkan maknanya yaitu kalimat berita dan kalimat seruan dalam naskah pidato Bung Karno tanggal 17 Agustus 1945. Penelitian ini penting dilakukan karena naskah pidato Bung Karno 17 Agustus 1945 yang menjadi pengantar proklamasi kemerdekaan yang berpengaruh besar terhadap kelangsungan negara Indonesia perlu diketahui bagaimana fungsi, peran, dan kategori sintaksis dalam kalimatnya.

Penelitian ini menggunakan metode deskriptif kualitatif. Moleong (2011:6) dalam (Yunregiarsih, Tarmini, \& Mustofa, 2014) menyatakan bahwa penelitian deskriptif kualitatif adalah penelitian yang bermaksud untuk memahami fenomena tentang apa yang dialami oleh subjek penelitian, misalnya perilaku, persepsi, motivasi, tindakan dan lain-lain, secara holistik, dan dengan cara deskripsi dalam bentuk kata-kata dan bahasa, pada suatu konteks khusus yang alamiah dan dengan memanfaatkan berbagai metode alamiah. Pada penelitian kualitatif, peneliti memiliki kedudukan khusus, yaitu sebagai perencana, pelaksana pengumpulan data, analis, penafsir data, serta pelapor hasil penelitiannya (Moleong, 2017). Fokus analisis kualitatif yaitu pada penunjukan makna, deskripsi, penjernihan, dan penempatan data pada konteksnya masingmasing dan sering kali melukiskannya dalam bentuk kata-kata daripada angka-angka (Mahsun, 2005). Penggunaan metode ini bertujuan untuk mendeskripsikan fungsi, peran, dan kategori sintaksis bahasa Indonesia dalam kalimat berita dan kalimat seruan pada naskah pidato Bung Karno 17 Agustus 1945. 
Pada penelitian ini teknik analisis data yang digunakan adalah analisis isi. Pengumpulan data untuk dianalisis menggunakan teknik simak catat. Teknik simak catat yang berfungsi untuk melakukan pencatatan data yang telah diperoleh. Setelah data dicatat, data tersebut diseleksi berdasarkan penggunaannya karena data berupa teks (Trisnawati A. , 2015). Data yang diperoleh kemudian diklasifikasikan menurut jenis objek penelitian yaitu kalimat deklaratif dan kalimat imperatif. Teknik analisis data dilakukan mulai dari awal berupa pengumpulan, pencatatan, dan klasifikasi. Data tersebut kemudian dianalisis sehingga dapat diperoleh fungsi, peran, dan kategori sintaksis dalam kalimat deklaratif dan imperatif dengan tepat. Setelah itu data yang sudah dianalisis disimpulkan.

Dengan adanya penelitian ini diharapkan dapat menunjukkan fungsi, peran, dan kategori sintaksis dalam kalimat deklaratif dan imperatif pada naskah pidato Bung Karno 17 Agustus 1945 yang merupakan pidato proklamasi kemerdekaan Indonesia.

\section{Hasil dan Pembahasan}

Fungsi, peran, dan kategori sintaksis dalam naskah pidato Bung Karno 17 Agustus 1945 sangat beragam. Salah satu diantaranya adalah fungsi, peran, dan kategori sintaksis yang terdapat dalam kalimat berita dan kalimat seruan pada naskah pidato Bung Karno 17 Agustus 1945. Kalimat berita digunakan Bung Karno untuk menyampaikan informasi aktual mengenai negara Indonesia yang akan merdeka dan kalimat seruan digunakan Bung karno untuk mengekspresikan semangat dalam memproklamasikan kemerdekaan Indonesia setelah ratusan tahun dijajah. Berikut adalah fungsi, peran, dan kategori sintaksis dalam kalimat berita dan kalimat seruan pada naskah pidato Bung Karno 17 Agustus 1945:

\section{Kalimat berita}

Kalimat berita merupakan kalimat yang isinya memberitahukan sesuatu kepada pembaca atau pendengar. Dalam naskah pidato Bung Karno 17 Agustus 1945 ini banyak ditemukan kalimat berita yang kemudian dianalisis dengan hasil sebagai berikut: 
a. Tabel 1.1 Fungsi, Peran, Kategori Sintaksis dalam Kalimat "Saya telah minta Saudara untuk menyaksikan satu peristiwa maha penting dalam sejarah kita."

\begin{tabular}{|l|l|l|l|l|}
\hline $\begin{array}{l}\text { Tataran } \\
\text { sintaksis }\end{array}$ & Saya & $\begin{array}{l}\text { Telah } \\
\text { minta }\end{array}$ & Saudara & $\begin{array}{l}\text { Untuk menyaksikan } \\
\text { satu peristiwa maha } \\
\text { penting dalam } \\
\text { sejarah kita }\end{array}$ \\
\hline Fungsi & S & P & 0 & Ket \\
\hline Kategori & Pronomina & $\begin{array}{l}\text { Frasa } \\
\text { adverbial }\end{array}$ & Pronomina & Frasa verbal \\
\hline Peran & Pelaku & Keadaan & Sasaran & Pemeri \\
\hline
\end{tabular}

Kalimat "Saya telah minta saudara untuk menyaksikan satu peristiwa maha penting dalam sejarah kita." Merupakan kalimat berita yang menjelaskan mengenai informasi faktual yang berkaitan dengan alam sekitar atau pengalaman penutur. Kata saya berfungsi sebagai subjek dengan peran pelaku berkategori pronomina. Frasa telah minta berfungsi sebagai predikat dengan peran menjelaskan suatu keadaan dan berkategori sebagai frasa adverbial. Kata saudara berfungsi sebagai objek dengan peran menjadi sasaran dan berkategori sebagai pronomina. Frasa untuk menyaksikan satu peristiwa maha penting dalam sejarah kita berfungsi sebagai keterangan dengan peran sebagai pemeri berkategori frasa verbal.

b. Tabel 1.2 Fungsi, Peran, Kategori Sintaksis dalam Kalimat "Gelombangnya aksi kita untuk mencapai kemerdekaan kita ini ada naiknya dan turunnya."

\begin{tabular}{|l|l|l|l|l|}
\hline $\begin{array}{l}\text { Tataran } \\
\text { sintaksis }\end{array}$ & $\begin{array}{l}\text { Gelombangnya } \\
\text { aksi kita }\end{array}$ & $\begin{array}{l}\text { Untuk } \\
\text { mencapai }\end{array}$ & $\begin{array}{l}\text { Kemerdekaan } \\
\text { kita ini }\end{array}$ & $\begin{array}{l}\text { Ada naik } \\
\text { dan } \\
\text { turunnya. }\end{array}$ \\
\hline Fungsi & S & P & 0 & K \\
\hline
\end{tabular}




\begin{tabular}{|l|l|l|l|l|}
\hline Kategori & Frasa nominal & Frasa verbal & Frasa nominal & $\begin{array}{l}\text { Frasa } \\
\text { verbal }\end{array}$ \\
\hline Peran & Alat & Peruntukkan & Hasil & Status \\
\hline
\end{tabular}

\section{Kalimat "Gelombangnya aksi kita untuk mencapai} kemerdekaan kita ini ada naik dan turunnya." merupakan kalimat berita untuk menyampaikan informasi faktual berkaitan dengan keadaan atau pengalaman penutur. Frasa gelombangnya aksi kita berfungsi sebagai subjek dengan peran sebagai alat berkategori frasa nominal. Frasa untuk mencapai berfungsi sebagai predikat dengan peran peruntukkan berkategori frasa verbal. Frasa kemerdekaan kita berfungsi sebagai objek dengan peran sebagai hasil berkategori frasa nominal. Frasa itu ada naik dan turunnya berfungsi sebagai keterangan dengan peran sebagai status berkategori frasa verbal.

c. Tabel 1.3 Fungsi, Peran, Kategori Sintaksis dalam Kalimat "Juga di dalam zaman Jepang, usaha kita untuk mencapai kemerdekaan nasional tidak berhenti."

\begin{tabular}{|l|l|l|l|l|l|}
\hline $\begin{array}{l}\text { Tatara } \\
\text { sintaksi } \\
\text { s }\end{array}$ & $\begin{array}{l}\text { Juga di } \\
\text { dalam } \\
\text { zaman } \\
\text { Jepang }\end{array}$ & $\begin{array}{l}\text { Usaha } \\
\text { kita }\end{array}$ & $\begin{array}{l}\text { Untuk } \\
\text { mencapai }\end{array}$ & $\begin{array}{l}\text { Kemerdeka } \\
\text { an nasional }\end{array}$ & $\begin{array}{l}\text { Tidak } \\
\text { berhenti }\end{array}$ \\
\hline Fungsi & K & S & P & O & Pel \\
\hline $\begin{array}{l}\text { Katego } \\
\text { ri }\end{array}$ & $\begin{array}{l}\text { Frasa } \\
\text { preposision } \\
\text { al }\end{array}$ & $\begin{array}{l}\text { Frasa } \\
\text { nomin } \\
\text { al }\end{array}$ & $\begin{array}{l}\text { Frasa } \\
\text { verbal }\end{array}$ & $\begin{array}{l}\text { Frasa } \\
\text { nominal }\end{array}$ & $\begin{array}{l}\text { Frasa } \\
\text { adjectiv } \\
\text { al }\end{array}$ \\
\hline Peran & Waktu & Alat & $\begin{array}{l}\text { Peruntukk } \\
\text { an }\end{array}$ & Sasaran & Pemeri \\
\hline
\end{tabular}

Kalimat "Juga di dalam zaman Jepang, usaha kita untuk mencapai kemerdekaan nasional tidak berhenti." merupakan kalimat berita untuk menyampaikan informasi mengenai keadaan atau pengalaman penutur. Frasa juga di dalam zaman Jepang berfungsi sebagai keterangan dengan peran menunjukkan waktu berkategori frasa preposisional. Frasa usaha kita berfungsi sebagai subjek dengan peran 
sebagai alat berkategori frasa nominal. Frasa untuk mencapai berfungsi sebagai predikat dengan peran peruntukkan berkategori frasa verbal. Frasa kemerdekaan nasional berfungsi sebagai objek dengan peran sasaran berkategori frasa nominal. Frasa tidak berhenti berfungsi sebagai pelengkap dengan peran pemeri berkategori frasa adjektival.

d. Tabel 1.4 Fungsi, Peran, Kategori Sintaksis dalam Kalimat "Di dalam zaman Jepang ini nampaknya saja kita menyandarkan diri kepada mereka."

\begin{tabular}{|c|c|c|c|c|c|}
\hline $\begin{array}{l}\text { Tatara } \\
\mathrm{n} \\
\text { sintaks } \\
\text { is }\end{array}$ & $\begin{array}{l}\text { Di dalam } \\
\text { zaman } \\
\text { Jepang ini }\end{array}$ & $\begin{array}{l}\text { Nampakn } \\
\text { ya saja }\end{array}$ & Kita & $\begin{array}{l}\text { Menyandark } \\
\text { an diri }\end{array}$ & $\begin{array}{l}\text { Kepad } \\
\text { a } \\
\text { merek } \\
\text { a }\end{array}$ \\
\hline Fungsi & K & Pel & $S$ & $\mathrm{P}$ & 0 \\
\hline $\begin{array}{l}\text { Katego } \\
\text { ri }\end{array}$ & $\begin{array}{l}\text { Frasa } \\
\text { preposision } \\
\text { al }\end{array}$ & $\begin{array}{l}\text { Frasa } \\
\text { adverbial }\end{array}$ & $\begin{array}{l}\text { Pronomi } \\
\text { na }\end{array}$ & Frasa verbal & $\begin{array}{l}\text { Frasa } \\
\text { nomin } \\
\text { al }\end{array}$ \\
\hline Peran & Waktu & Pemeri & Pelaku & Aktivitas & $\begin{array}{l}\text { Sasara } \\
\mathrm{n}\end{array}$ \\
\hline
\end{tabular}

Kalimat "Di dalam zaman jepang ini nampaknya saja kita menyandarkan diri kepada mereka." merupakan kalimat berita untuk menyampaikan informasi mengenai keaadan atau pengalaman penutur. Frasa di dalam zaman jepang ini berfungsi sebagai keterangan dengan peran menunjukkan waktu berkategori frasa preposisional. Frasa nampaknya saja berfungsi sebagai pelengkap dengan peran pemeri berkategori frasa adverbial. Frasa kita berfungsi sebagai subjek dengan peran pelaku berkategori pronomina. Frasa menyandarkan diri berfungsi sebagai predikat dengan peran sebuah aktivitas berkategori frasa verbal. Frasa kepada mereka berfungsi sebagai objek dengan peran sasaran berkategori frasa nominal.

e. Tabel 1.5 Fungsi, Peran, Kategori Sintaksis dalam Kalimat "Tetapi pada hakikatnya, tetap kita menyusun tenaga kita sendiri, tetap kita percaya kepada kekuatan sendiri." 


\begin{tabular}{|l|l|l|l|l|l|l|}
\hline $\begin{array}{l}\text { Tatara } \\
\text { sintaks } \\
\text { is }\end{array}$ & $\begin{array}{l}\text { Tetapi } \\
\text { pada } \\
\text { hakikatn } \\
\text { ya }\end{array}$ & $\begin{array}{l}\text { Tetap } \\
\text { kita }\end{array}$ & $\begin{array}{l}\text { menyus } \\
\text { un }\end{array}$ & $\begin{array}{l}\text { Tenag } \\
\text { a kita } \\
\text { sendiri }\end{array}$ & Percaya & $\begin{array}{l}\text { Kepada } \\
\text { kekuata } \\
\mathrm{n} \\
\text { sendiri }\end{array}$ \\
\hline Fungsi & $\mathrm{K}$ & $\mathrm{S}$ & $\mathrm{P}$ & $\mathrm{O}$ & $\mathrm{P}$ & O \\
\hline $\begin{array}{l}\text { Katego } \\
\text { ri }\end{array}$ & $\begin{array}{l}\text { Frasa } \\
\text { nominal }\end{array}$ & $\begin{array}{l}\text { Frasa } \\
\text { nomin } \\
\text { al }\end{array}$ & $\begin{array}{l}\text { Verba } \\
\text { transitif }\end{array}$ & $\begin{array}{l}\text { Frasa } \\
\text { nomin } \\
\text { al }\end{array}$ & $\begin{array}{l}\text { Verba } \\
\text { intransit } \\
\text { if }\end{array}$ & $\begin{array}{l}\text { Frasa } \\
\text { nomina } \\
\text { l }\end{array}$ \\
\hline Peran & Asal & Pelaku & Aktivitas & alat & $\begin{array}{l}\text { Aktivita } \\
\text { s }\end{array}$ & Alat \\
\hline
\end{tabular}

Kalimat "Tetapi pada hakikatnya, tetap kita menyusun tenaga kita sendiri, tetap kita percaya kepada kekuatan sendiri." merupakan kalimat berita untuk menyampaikan informasi mengenai keaadan atau pengalaman penutur. Frasa tetapi pada hakikatnya berfungsi sebagai keterangan dengan peran asal berkategori frasa nominal. Frasa tetap kita berfungsi sebagai subjek dengan peran pelaku berkategori frasa nominal. Frasa menyusun berfungsi sebagai predikat dengan peran sebagai aktivitas berkategori verba transitif. Frasa tenaga kita sendiri berfungsi sebagai objek dengan peran sebagai alat berkategori frasa nominal. Kata percaya berfungsi esbagai predikat denga peran sebagai aktivitas berkategori verba intransitif. Frasa kepada kekuatan sendiri berfungsi sebagai objek dengan peran sebagai alat berkategori frasa nominal.

f. Tabel 1.6 Fungsi, Peran, Kategori Sintaksis dalam Kalimat "Sekarang tibalah saatnya kita benar-benar mengambil nasib dalam tangan kita sendiri, akan dapat berdiri dengan kuatnya"

\begin{tabular}{|l|l|l|l|l|l|}
\hline $\begin{array}{l}\text { Tataran } \\
\text { sintaksis }\end{array}$ & $\begin{array}{l}\text { Sekarang } \\
\text { tibalah } \\
\text { saatnya }\end{array}$ & Kita & $\begin{array}{l}\text { Benar- } \\
\text { benar } \\
\text { mengam } \\
\text { bil }\end{array}$ & $\begin{array}{l}\text { Nasib dalam } \\
\text { tangan kita } \\
\text { sendiri }\end{array}$ & $\begin{array}{l}\text { Akan } \\
\text { dapat } \\
\text { berdiri } \\
\text { dengan } \\
\text { kuatnya }\end{array}$ \\
\hline Fungsi & K & S & P & O & Pel \\
\hline Kategori & $\begin{array}{l}\text { Frasa } \\
\text { nominal }\end{array}$ & $\begin{array}{l}\text { Pronomi } \\
\text { na }\end{array}$ & $\begin{array}{l}\text { Frasa } \\
\text { adjektiv } \\
\text { al }\end{array}$ & $\begin{array}{l}\text { Frasa } \\
\text { nominal }\end{array}$ & $\begin{array}{l}\text { Frasa } \\
\text { adjektival }\end{array}$ \\
\hline
\end{tabular}




\begin{tabular}{|l|l|l|l|l|l|}
\hline Peran & Waktu & Pelaku & Aktivitas & Sasaran & Pemeri \\
\hline
\end{tabular}

Kalimat "Sekarang tibalah saatnya kita benar-benar mengambil dalam tangan kita sendiri, akan dapat berdiri dengan kuatnya." merupakan kalimat berita untuk menyampaikan informasi mengenai keaadan atau pengalaman penutur. Frasa sekarang tibalah saatnya berfungsi sebagai keterangan dengan peran menunjukkan waktu berkategori frasa nominal. Kata kita berfungsi sebagai subjek dengan peran sebagai pelaku berkategori pronomina. Frasa benar-benar mengambil berfungsi sebagai predikat dengan peran sebagai suatu aktivitas berkategori frasa adjektival. Frasa nasib dalam tangan kita sendiri berfungsi sebagai objek dengan peran sebagai sasaran berkategori frasa nominal. Frasa akan berdiri dengan kuatnya berfungsi sebagai pelengkap dengan peran sebagai pemeri berkategori frasa adjektival.

g. Tabel 1.7 Fungsi, Peran, Kategori Sintaksis dalam Kalimat "Maka kita, tadi malam telah mengadakan musyawarah dengan pemuka-pemuka rakyat Indonesia, dari seluruh Indonesia"

\begin{tabular}{|l|l|l|l|l|l|}
\hline $\begin{array}{l}\text { Tataran } \\
\text { sintaksis }\end{array}$ & $\begin{array}{l}\text { Maka } \\
\text { kita }\end{array}$ & $\begin{array}{l}\text { Tadi } \\
\text { malam }\end{array}$ & $\begin{array}{l}\text { Telah } \\
\text { mengadakan }\end{array}$ & $\begin{array}{l}\text { Musyawarah } \\
\text { dengan } \\
\text { pemuka- } \\
\text { pemuka } \\
\text { rakyat } \\
\text { Indonesia }\end{array}$ & $\begin{array}{l}\text { Dari seluruh } \\
\text { Indonesia }\end{array}$ \\
\hline Fungsi & S & K & P & O & Pel \\
\hline Kategori & $\begin{array}{l}\text { Frasa } \\
\text { nominal }\end{array}$ & $\begin{array}{l}\text { Frasa } \\
\text { nominal }\end{array}$ & $\begin{array}{l}\text { Frasa } \\
\text { adjektival }\end{array}$ & Frasa verbal & $\begin{array}{l}\text { Frasa } \\
\text { preposisional }\end{array}$ \\
\hline Peran & Pelaku & Waktu & Aktivitas & Penerima & Pemeri \\
\hline
\end{tabular}

\section{Kalimat "Maka kita, tadi malam musyawarah dengan pemuka-} pemuka rakyat Indonesia, dari seluruh Indonesia." merupakan kalimat berita untuk menyampaikan informasi mengenai keaadan atau pengalaman penutur. Frasa maka kami berfungsi sebagai saubjek dengan peran sebagai pelaku berkategori frasa nominal. Frasa tadi malam berfungsi sebagai keterangan dengan peran menunjukkan waktu 
berkategori frasa nominal. Frasa berfungsi musyawarah dengan pemuka-pemuka rakyat Indonesia sebagai objek dengan peran penerima berkategori frasa verbal. Frasa dari seluruh Indonesia berfungsi sebagai pelengkap dengan peran pemeri berkategori frasa preposisional.

h. Tabel 1.8 Fungsi, Peran, Kategori Sintaksis dalam Kalimat "Permusyawaratan itu seia sekata berpendapat, bahwa sekaranglah datang saatnya menyatakan kemerdekaan kita."

\begin{tabular}{|l|l|l|l|l|}
\hline $\begin{array}{l}\text { Tataran } \\
\text { sintaksis }\end{array}$ & $\begin{array}{l}\text { Permusyawaratan } \\
\text { itu seia sekata } \\
\text { berpendapat }\end{array}$ & $\begin{array}{l}\text { bahwa } \\
\text { sekaranglah } \\
\text { datang } \\
\text { saatnya }\end{array}$ & Menyatakan & $\begin{array}{l}\text { kemerdekaan } \\
\text { kita }\end{array}$ \\
\hline Fungsi & S & K & P & O \\
\hline Kategori & Frasa nominal & $\begin{array}{l}\text { Frasa } \\
\text { nominal }\end{array}$ & Frasa verbal & $\begin{array}{l}\text { Frasa } \\
\text { nominal }\end{array}$ \\
\hline Peran & Alat & Waktu & Aktivitas & Hasil \\
\hline
\end{tabular}

Kalimat "Permusyawaratan itu seia sekata berpendapat, bahwa sekaranglah datang saatnya menyatakan kemerdekaan kita." merupakan kalimat berita untuk menyampaikan informasi mengenai keaadan atau pengalaman penutur. Frasa permusyawaratan itu seia sekata berpendapat berfungsi sebagai subjek dengan peran sebagai alat berkategori frasa nominal. Frasa bahwa sekaranglah datang saatnya berfungsi sebagai keterangan dengan peran menunjukkan awaktu berkategori frasa nominal. Frasa untuk menyatakan berfungsi sebagai predikat dengan peran suatu aktivitas berkategori frasa verbal. Frasa kemerdekaan kita berfungsi sebagai objek dengan peran sebagai hasil berkategori frasa nominal.

\section{Kalimat Seruan}

Kalimat seruan merupakan kalimat yang ditujukan untuk menunjukkan ekspresi di dalam diri seseorang, dapat berupa kekaguman, kemarahan, kekecewaan dan yang lainnya. Kalimat seruan adalah kalimat untuk mengungkapkan perasaan yang kuat. Dalam pelafalan kalimat seru ditandai dengan intonasi yang tinggi sedangkan dalam penulisan kalimat 
seru ditandai dengan tanda seru. Dalam naskah pidato Bung Karno 17 Agustus 1945 terdapat beberapa kalimat seruan yang dianalisis dengan hasil sebagai berikut:

a. Tabel 2.1 Fungsi, Peran, Kategori Sintaksis dalam Kalimat "Berpuluhpuluh tahun kita bangsa Indonesia telah berjuang untuk kemerdekaan tanah air kita, bahkan telah beratur-ratus tahun!"

\begin{tabular}{|l|l|l|l|l|l|}
\hline $\begin{array}{l}\text { Tataran } \\
\text { sintaksi } \\
\text { s }\end{array}$ & $\begin{array}{l}\text { Berpuluh } \\
\text {-puluh } \\
\text { tahun }\end{array}$ & $\begin{array}{l}\text { kita } \\
\text { bangsa } \\
\text { Indonesi } \\
\text { a }\end{array}$ & $\begin{array}{l}\text { telah } \\
\text { berjuan } \\
\text { g }\end{array}$ & $\begin{array}{l}\text { untuk } \\
\text { kemerdekaa } \\
\text { n tanah air } \\
\text { kita }\end{array}$ & $\begin{array}{l}\text { bahkan } \\
\text { telah } \\
\text { beratur- } \\
\text { ratus } \\
\text { tahun }\end{array}$ \\
\hline Fungsi & K & S & P & O & K \\
\hline $\begin{array}{l}\text { Kategor } \\
\text { i }\end{array}$ & $\begin{array}{l}\text { Frasa } \\
\text { numerali } \\
\text { a }\end{array}$ & $\begin{array}{l}\text { Frasa } \\
\text { nominal }\end{array}$ & $\begin{array}{l}\text { Frasa } \\
\text { verbal }\end{array}$ & $\begin{array}{l}\text { Frasa } \\
\text { nominal }\end{array}$ & $\begin{array}{l}\text { Frasa } \\
\text { numerali } \\
\text { a }\end{array}$ \\
\hline Peran & Waktu & Pelaku & $\begin{array}{l}\text { Aktivita } \\
\text { s }\end{array}$ & Sasaran & Waktu \\
\hline
\end{tabular}

Kalimat "Berpuluh-puluh tahun kita bangsa Indonesia telah berjuang untuk kemerdekaan tanah air kita, bahkan telah beratur-ratus tahun!" merupakan kalimat seruan untuk mengekspresikan kemarahan penutur karena pengalamannya atas penjajahan. Frasa berpuluh-puluh tahun berfungsi sebagai keterangan dengan peran menunjukkan waktu berkategori frasa numeralia. Frasa kita bangsa Indonesia berfungsi sebagai subjek dengan peran sebagai pelaku berkategori frasa nominal. Frasa telah berjuang berfungsi sebagai predikat dengan peran suatu aktivitas berkategori frasa verbal. Frasa untuk kemerdekaan tanah air kita berfungsi sebagai keterangan dengan peran menunjukkan waktu berkategori frasa nominal. Frasa bahkan telah beratur-ratus tahun berfungsi sebagai keterangan dengan peran menunjukkan waktu berkategori frasa numeralia.

b. Tabel 2.2 Fungsi, Peran, Kategori Sintaksis dalam Kalimat "Kita sekarang telah merdeka!"

\begin{tabular}{|l|l|l|l|}
\hline $\begin{array}{l}\text { Tataran } \\
\text { sintaksis }\end{array}$ & Kita & Sekarang & Telah merdeka \\
\hline
\end{tabular}




\begin{tabular}{|l|l|l|l|}
\hline Fungsi & S & K & P \\
\hline Kategori & Pronomina & Nomina & Frasa adjectival \\
\hline Peran & Pengalam & Waktu & Status \\
\hline
\end{tabular}

Kalimat “Kita sekarang telah merdeka!” merupakan kalimat seruan untuk mengekspresikan perasaan senang dan semangat penutur karena keadaan yang sudah berubah. Kata kita berfungsi sebagai subjek dengan peran sebagai pelaku berkategori pronominal. Kata sekarang berfungsi sebagai keterangan dengan peran menunjukkan waktu berkategori nomina. Frasa telah merdeka berfungsi sebagai predikat dengan peran menunjukkan status berkategori frasa adjektival.

d. Tabel 2.3 Fungsi, Peran, Kategori Sintaksis dalam Kalimat "Tidak ada satu ikatan lagi yang mengikat tanah air kita dan bangsa kita!"

\begin{tabular}{|l|l|l|l|}
\hline $\begin{array}{l}\text { Tataran } \\
\text { sintaksis }\end{array}$ & $\begin{array}{l}\text { Tidak ada satu } \\
\text { ikatan lagi }\end{array}$ & Yang mengikat & $\begin{array}{l}\text { Tanah air kita } \\
\text { dan bangsa kita }\end{array}$ \\
\hline Fungsi & S & P & O \\
\hline Kategori & Frasa adjektival & Frasa verbal & Frasa nominal \\
\hline Peran & Alat & Aktivitas & Sasaran \\
\hline
\end{tabular}

Kalimat "Tidak ada satu ikatan lagi yang mengikat tanah air kita dan bangsa kita!" merupakan kalimat seruan untuk mengekspresikan perasaan penutur yang bahagia karena keadaannya. Frasa tidak ada satu ikatan lagi berfungsi sebagai objek dengan peran sebagai alat berkategori frasa adjektival. Frasa yang mengikat berfungsi sebagai predikat dengan peran suatu aktivitas berkategori frasa verbal. Frasa tanah air kita dan bangsa kita berfungsi sebagai objek dengan peran sebagai sasaran berkategori frasa nominal.

e. Tabel 2.4 Fungsi, Peran, Kategori Sintaksis dalam Kalimat "Mulai saat ini kita menyusun negara kita!"

\begin{tabular}{|l|l|l|l|l|}
\hline $\begin{array}{l}\text { Tataran } \\
\text { sintaksis }\end{array}$ & $\begin{array}{l}\text { Mulai } \\
\text { saat ini }\end{array}$ & Kita & Menyusun & Negara kita \\
\hline
\end{tabular}


Enggarwati, Utomo: Fungsi, Peran, dan Kategori Sintaksis Bahasa Indonesia | 51

\begin{tabular}{|l|l|l|l|l|}
\hline Fungsi & K & S & P & O \\
\hline Kategori & $\begin{array}{l}\text { Frasa } \\
\text { nominal }\end{array}$ & Pronomina & $\begin{array}{l}\text { Verba } \\
\text { transitif }\end{array}$ & $\begin{array}{l}\text { Frasa } \\
\text { nominal }\end{array}$ \\
\hline Peran & Waktu & Pelaku & Aktivitas & Sasaran \\
\hline
\end{tabular}

Kalimat "Mulai saat ini kita menyusun negara kita!" merupakan kalimat seruan yang mengekspresikan ekspresi semangat dari penutur. Frasa mulai saat ini berfungsi sebagai keterangan dengan peran menunjukkan waktu berkategori frasa nominal. Kata kita berfungsi sebagai subjek dengan peran sebagai pelaku berkategori pronomina. Kata menyusun berfungsi sebagai predikat dengan peran sebagai suatu aktivitas berkategori verba transitif. Frasa negara kita berfungsi sebagai objek dengan peran sebagai sasaran berkategori frasa nominal.

Hasil penelitian ini melengkapi hasil penelitian yang dilakukan oleh (Mayasari, 2017) yang mengkaji tentang fungsi, peran, dan kategori sintaksis bahasa Indonesia dalam kalimat deklaratif dan kalimat imperatif pada rubrik harian Jawa Pos. Pada penelitian (Mayasari, 2017) peneliti menemukan fungsi dan peran sintaksis pada kalimat interogatif rubrik deteksi harian Jawa Pos memiliki keunikan, yaitu jika dalam kalimat pada umumnya memiliki pola fungsi subjek terlebih dahulu baru kemudian diikuti fungsi predikat, dalam penelitian ini uniknya pada kalimat berita ada yang mengandung dua predikat, dua keterangan, dan dua objek dalam satu kalimat sekaligus. Hal ini sesuai dengan hasil penelitian yang dilakukan oleh (Rina Tri Wahyuni, 2019) yang membahas tentang pola, fungsi, kategori, dan peran sintaksis pada kalimat tunggal dalam surat kabar harian Kompas serta relevansinya dengan pembelajaran bahasa Indonesia di SMP. Dalam hasil penelitian (Rina Tri Wahyuni, 2019) tersebut juga ditemukan dua fungsi predikat, fungsi subjek, dan fungsi keterangan dalam satu kalimat majemuk.

\section{Kesimpulan}

Dalam naskah pidato Bung Karno 1945, kalimat berita yang dianalisis berjumlah 8 kalimat dan kalimat seruan yang dianalisis berjumlah 4 kalimat. Fungsi sintaksis yang ditemukan dalam kalimat berita dan kalimat seruan pada naskah pidato Bung Karno 17 Agustus 
1945 terdapat 5 fungsi sintaksis meliputi subjek, predikat, objek, keterangan, dan pelengkap. Jenis-jenis peran yang ditemukan adalah sebagai pelaku, alat, dan pengalam menduduki fungsi subjek. Peran sebagai keadaan, peruntukkan, dan aktivitas menduduki fungsi predikat. Peran sebagai sasaran, hasil, dan penerima menduduki fungsi objek. Peran sebagai tempat dan status menduduki fungsi keterangan. Peran sebagai pemeri dan perlawanan menduduki fungsi pelengkap. Kategori yang terdapat dalam kalimat berita dan kalimat seruan pada naskah pidato Bung Karno 17 Agustus 1945 berjumlah 10 jenis kategori meliputi pronomina, nomina, verba transitif, verba intransitif, frasa adverbial, frasa verbal, frasa nominal, frasa preposisional, frasa adjektival, dan frasa numeralia. Berdasarkan hasil penelitian ini selain dapat mengetahui tataran sintaksis yaitu fungsi, peran, dan kategori yang terdapat dalam kalimat berita dan kalimat seruan pada naskah proklamasi Bung Karno 17 Agustus 1945, dapat juga diketahui bahwasanya dalam satu kalimat dapat mengandung lebih dari satu jenis fungsi, peran, dan kategori sintaksis.

\section{Bibliografi}

Astuti, S. P. (2017). Analisis Fungsi Sintaksis Kata Apa dan Mana dalam Bahasa Indonesia. Jurnal NUSA, 206-2015.

Chaer, A. (2012). Linguistik Umum. Jakarta: PT Rineka Cipta.

Chaer, A. (2015). Sintaksis Bahasa Indonesia Pendekatan Proses. Jakarta: PT Rineka Cipta.

Erni. (2016). Fungsi, Kategori, dan Peran Pronomina Persona Bahasa Muna Dialek Kambowa. Jurnal Bastra (Bahasa dan Sastra) E-Jurnal Pendidikan Bahasa dan Sastra Indonesia , 1-9.

Irmansyah. (2015). Struktur Kalimat Deklaratif Bahasa Muna. Humanika, $1-12$.

Iswara, A. A. (2015). Fungsi Sintaksis dan Peran Semantis Argumen Frasa Verba Bahasa Bali. Retorika: Jurnal Ilmu Bahasa, 388-402.

Kridalaksana, H. (2008). Kamus Linguistik. Jakarta: Gramedia Pustaka Utama.

Lestari, U. M. (2018). Struktur Kalimat Biografi Cut Nyak Din dan Implikasinya di SMA. Jurnal Kata (Bahasa, Sastra, dan Pembelajarannya), 1-12. 
Mahsun. (2005). Metode Penelitian Bahasa: Tahapan Strategi, Metode, dan Tekniknya. Jakarta: Raja Grafindo Persada.

Mardhatillah. (2016). Fungsi dan Kategori Kalimat Sederhana dalam Jurnal English Teaching Forum (Suatu Analisis Sintaksis). Skripsi, 116.

Mayasari, D. (2017). Fungsi dan Peran Sintakasis Bahasa Indonesia dalam Rubrik Harian Jawa Pos. Jurnal Sastranesia, 1-9.

Mayasari, D., \& Ardhana, N. R. (2018). Publikasi Bentuk Fungsi dan Kategori Sintaksis Tuturan Masyarakat Manduro sebagai Pendukung Perkembangan Bahasa Anak Usia Dini. Obsesi: Jurnal Pendidikan Anak Usia Dini, 54-63.

Moleong, L. J. (2017). Metodologi Penelitian Kualitatif. Bandung: PT. Remaja Rosdakarya.

Nisrina, R. A. (2011). Struktur Frasa Pengisi Predikat pada Kumpulan Romansa Jawa Tembange Wong Kangen. Skripsi, 1-56

Sako, Y., Roekhan, \& Sunoto. (2017). Kesalahan Berbahasa Tataran Sintaksis pada Penulisan Pengalaman Pribadi Siswa Kelas X SMA . Jurnal Pendidikan: Teori, Penelitian, dan Pengembangan, 15271533.

Samu, A. Y. (2018). Fungsi Sintaksis dan Peran Semantis Argumen Inti Bahasa Manggarai Dialek Manggarai Tengah. Linguistik Indonesia, 188-204.

Susandhika, I. G., Laksana, I. K., \& Suparwa, I. N. (2016). Fungsi, Kategori, dan Peran Sintaksis Dalam Talk Show One Lawyers Club. Linguistika, 0-36.

Syahroni, A. W., \& Harsono. (2019). Aplikasi Penentuan Kategori dan Fungsi Sintaksis Kalimat Bahasa Indonesia. InfoTekJar: Jurnal Nasional Informatika dan Teknologi Jaringan, 12-20.

Taib, R. (2014). Analisis Kategori, Fungsi, dan Peran dalam Kalimat Bahasa Aceh. Metamorfosa, 43-54.

Trisnawati, A. (2015). Fungsi, Kategori, dan Peran Sintaksis Kalimat pada Pupuh Durma dalam Geguritan Tirta Amerta. Universitas Udayana, 1-26.

Usman, \& Amir, J. (2019). Pengaruh Kompetensi SintaksisTerhadap Keterampilan Menulis Eksposisi Mahasiswa Prodi Pendidikan Bahasa Indonesia UNM. Prosiding Seminar Nasional LP2M UNM 
54 | ESTETIK : Jurnal Bahasa Indonesia, vol. 4, no. 1, 2021

(pp. 516-525). Makasar: Universitas Negeri Makasar.

Wahyuni, R. T. (2019). Analisis Pola, Fungsi, Kategori, dan Peran Sintaksis pada Kalimat Tunggal dalam Surat Kabar Harian Kompas serta Relevansinya dengan Pembelajaran Bahasa Indonesia di SMP. Skripsi, 1-60.

Yunregiarsih, L. G., Tarmini, W., \& Mustofa, A. (2014). Pola Sintaksis pada Poster dan Implikasinya dalam Pembelajaran Bahasa Indonesia di SMP. Jurnal Kata (Bahasa, Sastra, dan Pembelajarannya), 1-12. 